\title{
NOTES ON THE GENUS CLITORIA (LEGUMINOSAE) IN PANAMA
}

\author{
Thomas B. Croat*
}

Missouri Botanical Garden, St. Louis, Missouri

There are 6 species of Clitoria in Panama. Several problems concerning delimitation of these species throughout their range, as well as problems of nomenclature, have prompted this discussion of Panamanian species of Clitoria. A key to these species follows:

A. Leaves 5-9 foliate

A. Leaves 3 -foliate:

Clitoria ternatea L.

1.

B. Plants herbaceous or at most suffruticose, not lianas or trees:

C. Stems and petioles glabrous or nearly so; reticulate veins prominently raised on both surfaces; plants usually unbranched

Clitoria guianensis (Aub1.) Benth. 4. var. subsessilis (Rose) Croat

C. Stems and petioles conspicuously pubescent; reticulate veins not at all raised; plants often branched:

D. Leaf blades acuminate at apex; calyx less than $1.5 \mathrm{~cm}$ long

Clitoria multiflora Mart. \& Gal. 3.

D. Leaf blades rounded to retuse at apex; calyx more than $2 \mathrm{~cm}$ long

Clitoria rubiginosa Juss.

B. Plants lianas, shrubs or trees:

E. Lianas; flowers

cauliflorous; calyx ca. $2.5 \mathrm{~cm}$ long; standard white or pinkish, with reddish stripes, 5-8 cm long; fruits usually conspicuously and densely pubescent, dark brown, more than $20 \mathrm{~cm}$ long; flowering mostly December to May.

Clitoria javitensis (H.B.K.) Benth. 5.

* Credit is given to Mr. Paul R. Fantz, University of Florida, a student of Clitoria, who reviewed the manuscript and gave helpful suggestions. 
E. Shrubs or trees, usually more than $6 \mathrm{~m}$ tal1; flowers cauliferous; calyx $1.5 \mathrm{~cm}$ long; standard violet (keel \& wing petals white), less than $2.5 \mathrm{~cm}$ long; fruits glabrate, tan, less than $15 \mathrm{~cm}$ long; flowering July to December Clitoria glaberrima Pittier

1. Clitoria ternatea L., a native of the 01d World tropics, is now widespread in cultivation throughout the New World tropics, but especially in areas flanking the Caribbean.

2. Clitoria rubiginosa Juss. ranges throughout the New World tropics. Clitoria glycinoides DC., a name commonly used in the West Indies and South America, is a synonym. Clitoria rubiginosa is found in disturbed open areas in Panama, in tropical dry forest, premontane moist forest, and tropical moist forest along the Pacific slope (Holdridge Life-Zone System).

3. Clitoria multiflora Mart. \& Gal. is known in Panama only from Chiriqui Province in Western Panama. It was collected in premontane wet forest. I am not familiar with this species. It is possible that it should be referred to as $\underline{\mathrm{C}}$. polystachya Benth., which is a slightly older name than $\underline{\mathrm{C}}$. multiflora.

4. Central American plants going by the name Clitoria guianensis (Aub1.) Benth. and West Indian plants called either Clitoria cajanifolia (Pres1) Benth. or C. laurifolia Poir. (a synonym of $\underline{\text { C. }}$ cajanifolium) are subspecifically distinct from $\underline{C}$. guianensis. Recognition of this taxon was first made by Rose (1899) in a discussion of Mexican Clitoria. The taxon is, however, not distinct at the level of species and the following recombination is therefore proposed.

\section{Clitoria guianensis (Aub1.) Benth.}

var. subsessilis (Rose) comb. novo.

Clitoria subsessilis Rose,

Contr. U.S. Nat1. Herb. 5: 169. 1899. Lectotype

Nelson 2748 (US).

Clitoria guianensis var. subsessilis ranges from Mexico

to Panama and is also found in the West Indies. In Panama the species occurs in savannas and roadsides on the Pacific slope in tropical dry forest and premontane moist forest. Clitoria guianensis var. subsessilis appears to be morphologically intermediate between $\underline{C}$. guianensis var. guianensis and $\underline{C}$. cajanifolia. It differs from the typical variety of C. guianensis principally in having usually broader leaflets which are dull and glaucous beneath. Clitoria guianensis has leaves which are slender (usually less than $1.5 \mathrm{~cm}$ broad), shiny and not glaucous on lower surface. Clitoria guianensis 
var. subsessilis has leaves which are similar to $\underline{\mathrm{C}}$. cajanifolia in superficial appearance but that species has the lower blade surface much more pubescent. Clitoria cajanifolia also differs greatly in habit. Plants are usually much larger (usually much more than a meter tall) and they are also often more or less scandent. Both the typical variety of $\underline{C}$. guianensis and the var. subsessilis are short suffruticose plants usually about $30 \mathrm{~cm}$ tall.

Bentham (1858) in his brief monograph of C1itoria reported $\underline{C}$. cajanifolia for both South America and the West Indies but did not mention the glaucous condition of the leaves. I assume that his descriptions were based principally on South American collections of $\underline{C}$. cajanifolia rather than on West Indian collections.

5. The two remaining species of Clitoria in Panama, C. javitensis (H.B.K.) Benth. and C. glaberrima Pittier, have long been confused with each other, despite their very obvious differences. Clitoria javitensis (H.B.K.) Benth. has undergone a series of nomenclatural changes in Panama. It was long called $\underline{\text { C. }}$ arborescens Ait., a species from St. Vincent (Lesser Antilles), Trinidad, and the Guianas. Later it was considered a distinct species and called $\underline{\text { C. }}$. portobellensis Beurl., the type of which is from Panama in Colon Province. It has now become obvious however after studying specimens from throughout its range that the Panamanian material is not distinct from South American plants going by the older name C. javitensis (H.B.K.) Benth.

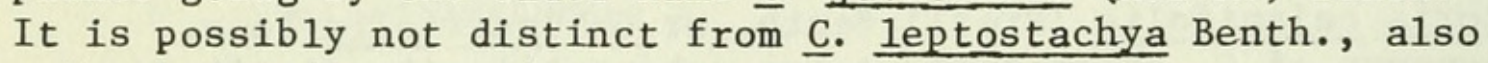
a South American species.

Clitoria javitensis (H.B.K.) Benth., as now considered to include $\underline{C}$. portobellensis Beurl., thus ranges from Panama to Colombia, the Guianas, northern Brazi1, Peru, and Ecuador. This is in agreement with Amshoff in her 1939 treatment of the Papilionaceae for the Flora of Surinam where she included

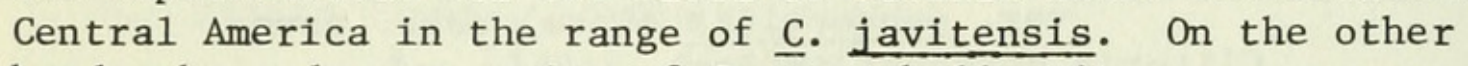
hand, she made no mention of $\underline{C}$. portobellensis.

Clitoria javitensis is usually a slender liana with a stem usually no more than $1.5 \mathrm{~cm}$ diam. It occurs in densely forested areas of tropical moist forest. In Panama it is known from the Atlantic slope of the isthmus in the vicinity of the Canal Zone, in the Perlas Islands in the Gulf of Panama (Panama Province) and in Darien Province. The species rarely occurs in open areas such as those reported by Johnston in the Flora of San Jose Island. Possibly the area was a disturbed site and the plants were merely persisting there after the forest had been removed. In such cases where the plant has been found in open areas it may form an erect shrub, no doubt the result of a loss of support. 
Clitoria javitensis possibly flowers and fruits to some extent all year but flowers have been seen only from October to May. Flowering is at its peak in the dry season from December to May. Mature fruits have been seen from January to May.

Because of the long standing confusion in Panama between C. javitensis (H.B.K.) Benth. and Clitoria glaberrima Pittier, the following exsiccatae is given for Panamanian specimens of both species. All specimens are at the Missouri Botanical Garden Herbarium (MO) unless otherwise indicated.

\section{Clitoria javitensis (H.B.K.) Benth.}

CANAL ZONE: Barro Colorado Island: Aviles 85; Croat 4216, $4615,4853,4967,5067,5285,5333,5595,6605,6734,7071$, $7077, \underline{7091}, \overline{7340}, \underline{7732}, \underline{7929}, \underline{8289}, \underline{8497}, \underline{8905}, \underline{9310}, \underline{12847}$; Dwyer 8452; Kil1ip 40034; Shattuck 312; Standley 41137 (US); Wetmore \& Abbe 6, 6A; Wilson 23, Woodworth \& Vesta1 675; Frijoles, Croat 13223 ; Las Cascadas Plantation, Standley 29557 (US), 29757 (US); Darién Station, Standley 311630 (US), 311634 (US); Between France Field and Catival, Standley 30327 (US), 30429 (US); Vicinity of Ft. Sherman, Standley 31058 (US); Vicinity of Gamboa, Allen 3931; Gamboa Pipeline Road on Tropic Test Center land, M. Correa A. \& B. L. Haines 481; Obisbo, Standley 31689 (US); Río Paraiso above E. Paraiso, Standley 29893 (US); Westerly arm of Quebrada Salamanca, Dodge, Steyermark \& Allen 17007. CHIRIQUI: Remedios and vicinity, Pittier 5469 (US). COLON: Juan Mina plantation, Río Chagres, Region above Gamboa, Allen 4114. DARIEN: Mannene to mouth of Rio Cuasi, Kirkbride \& Bristan 1402; Vicinity of Piñas, Duke 10617; Río Sambú 0-5 mi above Rio Venado, Duke 9262; Tucutí, Chepigana District, Terry \& Terry 1372.

PANAMA: Sabanas near Chepo, Hunter \& Allen 92; Isla de 1 Rey, Duke 9529: San José Island, Erlanson 29 (US), I. Johnston 670 (MO, US); Taboga Island Standley 27915 (US). VERAGUAS: Isla Coiba, A. Mendez 143 (US).

\section{Clitoria glaberrima Pittier is reported here for} Panama for the first time. It was known previously only from Venezuela. It apparently has a more restricted range than C. javitensis in Panama. It is known only from drier parts of tropical moist forest in the Canal Zone near Madden Lake, and along the Pacific Ocean and from the tropical dry forest in Panama Province, on Isla Tabaguilla and in Los Santos Province. It is also known from premontane moist forest in the Canal Zone. Clitoria glaberrima is always a shrub or tree $3.5-13 \mathrm{~m}$ tall. It flowers during the rainy season from July to December. The fruits mature from October to January. 


\section{Clitoria glaberrima Pittier (A11 MO)}

CANAL ZONE: Farfan Beach area, Tyson 1833, 1839; Tyson \& Blum 2606, 2618, 2619, 2620; Tyson, Dwyer \& B1um 3172; Madden Dam, Alt. $50 \mathrm{ft}$. Lewis, Dwyer \& Elias 8; Woodson, Allen \& Seibert 1553; Correa \& Dressler 353; Madden Dam, Boy Scout Camp Road, Dwyer 8387, 9166; Hi11 above Thatcher Ferry Bridge, Croat 17012. PANAMA: Is la Tabaguilla, Duke 5882. LOS SANTOS: Las Tablas, Dwyer 1180.

\section{LITERATURE CITED}

Amshoff, G. J. H., 1939. Papilionaceae in Pulle, Flora of Surinam 2(2): 1-257.

Bentham, G., 1858. Synopsis of the genus Clitoria, J. Linn. Soc. Lond. 2: 33-44.

Rose, J. N. 1899. Notes on Mexican species of Clitoria. Cont. U.S. Nat1. Herb. 5: 168-170. 


\section{$2 \mathrm{BHL}$ Biodiversity Heritage Library}

Croat, Thomas B. 1974. "Notes on the genus Clitoria (Leguminosae) in Panama." Phytologia 29, 130-134. https://doi.org/10.5962/bhl.part.13100.

View This Item Online: https://www.biodiversitylibrary.org/item/48965

DOI: https://doi.org/10.5962/bhl.part.13100

Permalink: https://www.biodiversitylibrary.org/partpdf/13100

\section{Holding Institution}

New York Botanical Garden, LuEsther T. Mertz Library

\section{Sponsored by}

The LuEsther T Mertz Library, the New York Botanical Garden

\section{Copyright \& Reuse}

Copyright Status: In copyright. Digitized with the permission of the rights holder.

Rights Holder: Phytologia

License: http://creativecommons.org/licenses/by-nc-sa/3.0/

Rights: https://biodiversitylibrary.org/permissions

This document was created from content at the Biodiversity Heritage Library, the world's largest open access digital library for biodiversity literature and archives. Visit BHL at https://www.biodiversitylibrary.org. 